\title{
Physicochemical and Nutritional Values of Some Recipes Made of Bananas and Plantains consumed in the East Region of Cameroon
}

\section{${ }^{1 \& 2 *} \mathrm{NGOH}$ Newilah GB, ${ }^{1}$ MANJIA Ngoungoure SU, ${ }^{2}$ TEMBE Tembe J, ${ }^{2}$ NKOUANDOU M, ${ }^{2}$ NGOMBI Ngombi E, ${ }^{1}$ KENDINE Vepowo C, ${ }^{1}$ KUIATE JR}

\author{
${ }^{1}$ University of Dschang, Department of Biochemistry - 67 Dschang, Cameroon. \\ ${ }^{2}$ Centre Africain de Recherches sur Bananiers et Plantains, Postharvest Technology \\ Laboratory - 832 Douala, Cameroon.
}

Article No.: 011318005

Type: Research

DOI: 10.15580/GJAS.2018.2.011318005

Submitted: 13/01/2018

Accepted: $16 / 01 / 2018$

Published: $28 / 02 / 2018$

${ }^{*}$ Corresponding Author

Ngoh Newilah Gerard Bertin

E-mail: gerard.ngoh @univ-

dschang.org, gbngoh

@gmail.com

Keywords: recipes, bananas ano plantains, physicochemical, nutritional, Cameroon
BACKGROUND. In order to evaluate and improve people's nutritional status, it is essential to know the nutrient contents of food in general, and that of processed food in particular since the treatments the latter undergo are likely to modify their nutritional characteristics. This study aimed to contribute to the assessment of the nutritional composition of dishes made of bananas or plantains consumed in the East region of Cameroon, thereby providing additional data suitable for improving the nutritional status of populations of this region in particular and that of Cameroon in general. METHODS. Consumption and culinary surveys were conducted with 88 households in Bertoua, Dimako and Abong-mbang through a participatory approach. Following these surveys, samples of dishes were collected for macronutrients (carbohydrates, lipids and proteins), ash and dry matter content analysis using AOAC recommended methods. Micronutrients were assessed using atomic absorption spectrophotometry, while simple chemical techniques were used for the determination of $\mathrm{pH}$, total titratable acidity (TTA) and total soluble solids (TSS). RESULTS. People of the East region of Cameroon cook and eat dishes derived from either bananas or plantains. Recipes of the 10 most consumed dishes have been clearly described. pH, TSS, TTA of the dishes depends of the repining stage of plantains or banana use in the dishes preparation. Micronutrient analyses showed high amounts of mineral elements in various dishes. The high energy value of Koukoul, Malaxé of plantain, Banana fritter could be assumed to the lipids content of the dishes as a results of oil add while preparing the dishes. CONCLUSIONS. Recipes generally containing banana and other ingredients are usually balanced as it is the case of "Malaxé of plantain" (47.14\% carbohydrates, $12.21 \%$ proteins and $32.25 \%$ lipids) which can cover the recommended daily food intake and contribute to the improvement of the nutritional status of Cameroonians. 


\section{INTRODUCTION}

For a proper well-being, man must eat variety of foods deriving either from animals or plants which contain nutrients Tremolieres et al. (1984) necessary for physiological functions such as basal metabolism, physical activity, growth, lactation Dupin et al. (1996). Malnutrition defined as an imbalance between food intake and food expenditure is responsible for many socioeconomic problems to human beings (The World Bank, 2006). In Cameroon, the loss of productivity due to inadequate intakes of nutrients between 2002 and 2011 was evaluated at 583 billion CFAF and about $33 \%$ of children less than 5 years suffer from chronic malnutrition (INS, 2012).

Plantains and cooking bananas are staple food crops for approximately 70 million of central and occidental African inhabitants (Tchango Tchango and Ngalani, 1998). In Cameroon, plantains are consumed fresh as desserts at ripen stages for some cultivars or processed (into boiled pulps, fried pulps, dried pulps, pounded pulps, etc.) either at green or ripen stages for almost all cultivars. They are generally eaten cooked or boiled green/unripe and eaten as a vegetable, fried when ripe or unripe to make fried-ripe-plantains or chips, baked when ripe or green, mashed, etc. (Ngoh Newilah et al., 2005). Bananas and plantains constitute the third staple food crop after rice and cassava Dury et al. (2002). According to Chandler (1995), bananas are energy-rich foods (100g yielding $90 \mathrm{Kcal})$, and are important sources of minerals (potassium, calcium, magnesium, phosphorus) and vitamins (A, B6, C). In 2010, bananas and plantains production in Cameroon was estimated at 1.33 and 3.18 millions of tons respectively, with the East Region producing 863.626 tons of plantain alone (AGRI-STAT, 2012).

In spite of the aforementioned characteristics, Cameroonians still suffer from malnutrition, especially the inhabitants of the East Region. Inge et al. (2004) and Trèche (1989) stressed out the importance of consuming food capable of fulfilling both energy and nutrients requirements with respect to the physiological status and the eating habits of an individual. Before consumption, food undergoes various treatments which may affect its nutrients content. Thus, the nutritional problems of the population may be due to the methods of preparation of bananas and plantains. Cooking often leads to physicochemical and nutritional modification of food (Kumar and Aalbersberg, 2006), and recipes are often made of various ingredients which contribute together to the food quality.

The objective of this work was to contribute to the assessment of the nutritional value of dishes made from either bananas or plantains produced and consumed in the East region of Cameroon, hence providing additional data suitable for improving the nutritional status of populations of this region in particular and that of Cameroon as a whole.

\section{MATERIALS AND METHODS}

\section{Study area}

This study was carried out from November $19^{\text {th }} 2014$ to January $13^{\text {th }} 2015$ in three localities of the East region of Cameroon, namely Bertoua, Dimako and Abongmbang.

\section{Surveys and sampling}

A consumption survey was conducted with 88 households in the cities of Bertoua, Dimako and Abong-mbang to identify dishes made from either banana or plantain consumed by these populations. During the household visits, careful observations and measurements were made to identify the type and quantity of ingredients as well as the chronology of operations used to prepare the dishes and the time of preparation. Each prepared meal collected from either 2 or 3 families, was cooled at room temperature, wrapped in aluminium foil, put in a polyethylene bag and packed in a plastic jar. The samples were first frozen in a home freezer and packed in an icebox, then transported to a laboratory of the African Research Center on Bananas and Plantains (CARBAP) and stored at $-20^{\circ} \mathrm{C}$ prior to analyses.

\section{Physicochemical and nutritional analyses}

\section{Physicochemical analysis}

Apart from the dry matter content which was done directly on the fresh sample, the other analyses were performed on dry powders obtained by blending the lyophilized samples.

Dry matter content was assessed directly on the fresh sample in an oven at $105^{\circ} \mathrm{C}$ until constant weight. Ash content was done by incineration in a muffle furnace at $550^{\circ} \mathrm{C}$ for 2 hours. The $\mathrm{pH}$ was measured with a $\mathrm{pH}$ meter. Total titratable acidity (TTA) was assessed manually by titration with $0.1 \mathrm{~N}$ Sodium Hydroxide until the endpoint of the reaction characterized by the change in color of the phenolphthalein indicator (from colorless to pink/red). Results were expressed as milliequivalent per litre sample in terms of malic acid which is the predominant acid present in bananas and plantains according to Josylin (1970). Total soluble solids (TSS) were performed using a Hand-held refractometer which measures TSS as ${ }^{\circ} \mathrm{Brix}$ in $0.1 \%$ graduations.

\section{Nutritional analysis}

Proteins were analyzed by total nitrogen determination using Kjeldahl method and the conversion factor of 6.25; meanwhile total lipids were determined by extraction in a Soxhlet apparatus for 12 hours using hexane as solvent (Bourely, 1982). Carbohydrates were obtained by the difference method (AOAC, 1980). The energy values of the dishes were calculated using energy conversion factors according to Atwater and Bryant (1990). The minerals (Calcium, Magnesium, Sodium, Potassium, Iron, Copper, Zinc, Manganese and lodine) were determined using an 
atomic absorption spectrophotometer while phosphorus was determined by colorimetry Pauwels et al. (1992).

\section{Statistical analysis}

Data on the composition of banana and plantain derived foods were evaluated by means of one-way analysis of variance using statistical package SPSS 16.0. Differences between samples were tested according to Duncan Waller test and considered to be significant when $\mathrm{p}<0.05$.

\section{RESULTS AND DISCUSSION}

\section{Description of the recipes}

The survey revealed 10 most consumed recipes in the Eastern region of Cameroon: "mashed plantain" or Ndengué, "Pounded plantain" or Ntuba, "Plantain gruel" or Boulesoual, "Plantain paste with unrefined palm oil" or "Koukoul", "Tisane de plantain", "Boiled plantain", "Malaxé of plantain", "Fritters of ripe banana paste", "Fried plantains" and "Roasted plantain". Table 1 displays their description with approximate quantity of ingredients for preparation.

\section{Culinary preparation of the recipes}

\section{Plantain gruel "Boulesoual"}

- $\quad$ Peel the ripe plantains and slice the pulps in small pieces;

- $\quad$ Put the sliced pulps in a pot, add water, pepper, and citronella leaves;

- $\quad$ Boil the mixture for about $23 \mathrm{~min}$;
- After the preparation, if there is still water, remove it and keep aside;

- Use a pestle to completely grind the cooked pulps;

- After grinding the pulps add the kept water to obtain a mushy drinkable substance.

According to the local consideration, pepper is used to avoid stomach pain because of the sugar level of plantain used for the preparation.

\section{Mashed plantain or "Ndengué"}

- Peel both the unripe and perfectly ripe plantains and slice them into small pieces;

- $\quad$ Add water and cook for about $30 \mathrm{~min}$;

- After the preparation, if there is still water, removed it and keep aside;

- $\quad$ Use a pestle to partially grind the cooked pulps;

- $\quad$ Add the water to obtain the purée.

Mashed plantain is used as a starchy complement and is eaten with some mocal sauces as well as fried beans. According to local assertion the ground plantain facilitates digestion and avoids stomach pain, so "Ndengué" can be suitable for infants, the elderly and people suffering from stomach pain.

\section{"Malaxé of plantain"}

- Peel the plantains and slice the pulps into small pieces;

- $\quad$ Wash the sliced pulps and put them in a clean pot;

- Add the slices, tomatoes and onions;

- Grind ginger, garlic, white pepper, black pepper and add to the mixture;

- $\quad$ Add salt, water and palm oil;

- Cook for about 26 min. 
Table 1: Recipes composition

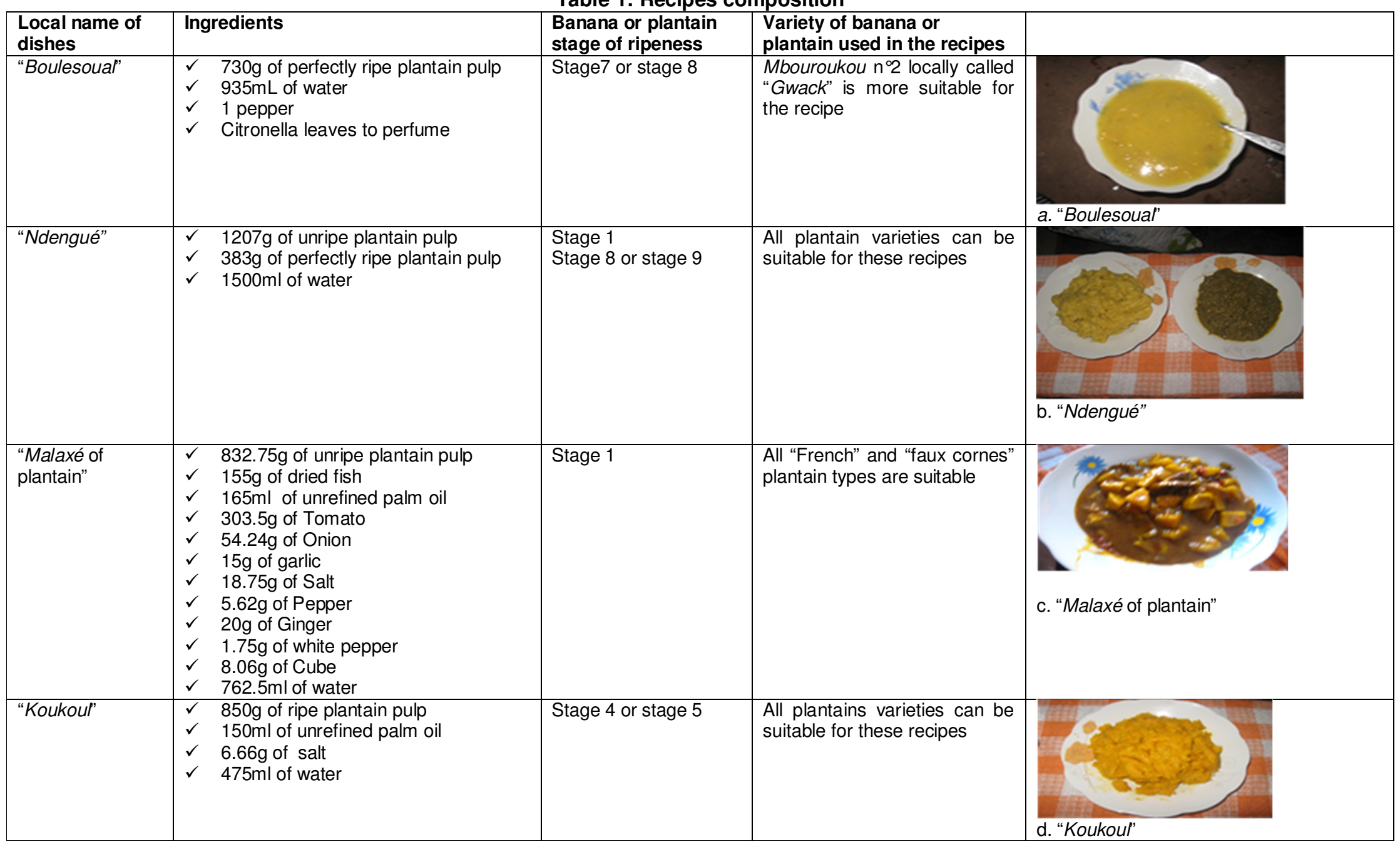




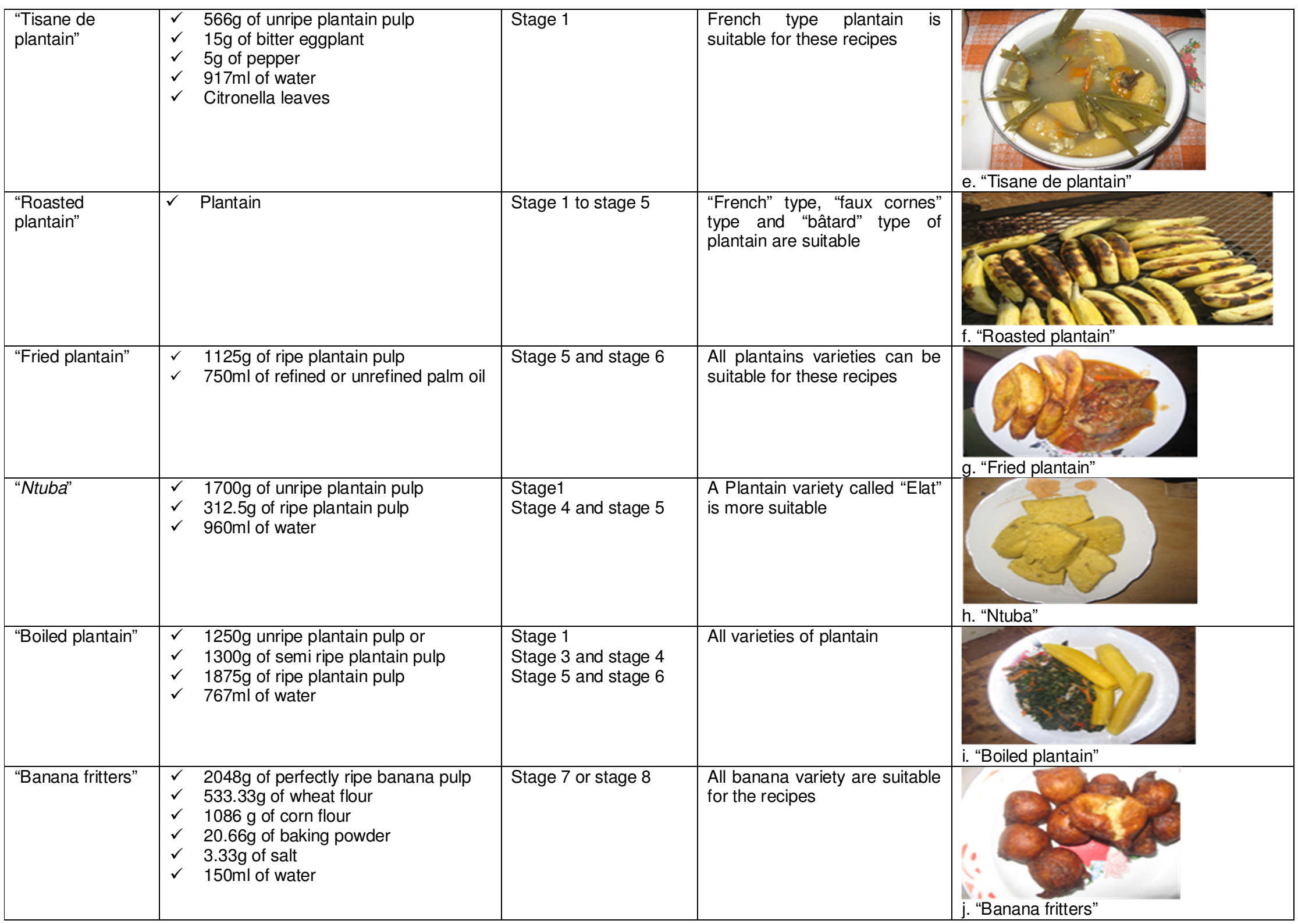




\section{Plantain paste with unrefined palm oil or "Koukoul"}

- Peel the plantains and slice the pulps to ease cooking;

- $\quad$ Add salt and water and cook till water evaporates completely;

- With a pestle grind the cooked pulps;

- $\quad$ Add unrefined palm oil in the paste and mix gently;

Serve or roll up and cut the paste with a knife before serving.

\section{"Tisane de plantain"}

- Peel the unripe plantains and scrap the tiny membrane covering the pulp;

- $\quad$ Cut the pulps in two pieces and put them in a pot;

- $\quad$ Add eggplant, citronella leaves, pepper and water;

- $\quad$ Cook the mixture for about 28 min and serve hot.

According to local assertion this recipe stimulates the production of breast milk.

\section{“Roasted plantain"}

- Peel the plantains and make cross incisions on the pulps to facilitate the roasting;

- Roast the pulps on a wire-netting using charcoal (as heat source);

- Turn the pulps from time to time to let the other sides be in contact with heat, until the pulps become soft.

The roasted plantain is eaten with palm oil, roasted plum, meat (chicken, pork, beef) and sauces.

\section{"Fried plantain"}

- Peel the ripe plantains and slice the pulps transversally in pieces of about $1.5 \mathrm{~cm}$;

- Fry the pulp in hot oil (refined and unrefined) for about $7 \mathrm{~min}$;

- Use a skimmer to remove the fried plantains from the frying oil and put them in a colander to let oil go out.

Fried plantain can be eaten with fried eggs, fried fish, tomato sauce, fried vegetables, and other roasted meats.

\section{Pounded plantain or "Ntuba"}

- Peel both the unripe and ripe plantains, cut the pulp into two pieces;

- Wash the pieces and put them in a pot;

- $\quad$ Add water and boil for about 35 min;
- Remove the boiled pulps, chill them first or pound them directly when the pulps are still hot in a mortar using a pestle;

- Pound vigorously to obtain a homogeneous paste;

- Wrap up the paste in banana leaves or use a thread to cut the paste and serve it.

"Ntuba" is eaten with groundnut soup, tomato sauce, fried vegetables, etc.

\section{"Boiled plantain"}

- Peel the plantains and scrap the tiny membrane covering the pulps;

- Wash the pulps and cut them into two pieces if the plantain pulps are big;

- Put the pulps in a clean pot, add water and boil for about 26 min depending on the fruit's grade (for a rapid water diffusion, water can first be boiled before introducing the plantain pulps).

Boiled plantain is eaten with sauces (tomato or groundnut), fried vegetables and beans.

\section{"Banana fritter"}

- Peel the perfectly ripe bananas and pound the pulps;

- Add wheat flour, corn flour, baking powder and mix vigorously to obtain a homogeneous paste;

- Add a bit of water to soften the paste;

- Put the paste in a container, close it and allow to rest for 15 to $30 \mathrm{~min}$;

- Heat the palm oil (refined or unrefined) that will be used for frying;

- Cut the paste into small pieces and put them in the hot oil;

- Fry for about 10 min turning it over frequently to let the other sides get fried too.

Banana fritter can be eaten with fried fish, fried beans.

\section{Physicochemical characteristics}

Table 2 presents the physicochemical characteristics of the 10 most consumed dishes made from either banana or plantain by the population of the East region of Cameroon. The dry matter of the different dishes ranged from $15.85 \%$ DW ("Boulesoual') to $63.33 \%$ DW ("Banana fritters") and their moisture content were respectively $36.67 \% \mathrm{FW}$ and $84.15 \% \mathrm{FW}$. The ash content of the different dishes ranged from $4.75 \%$ DW ("Boulesoual") to $15.42 \%$ DW ("Fried plantain"). The TSS varied from $23.20 \mathrm{~g} / \mathrm{l}$ ("Tisane de plantain") to $54.70 \mathrm{~g} / \mathrm{l}$ ("Boulesouaf"). TTA ranged from 2062.50 $\mathrm{mEq} / 100 \mathrm{~g}$ DW ("Malaxé of plantain") to 4875.00 $\mathrm{mEq} / 100 \mathrm{~g} \mathrm{DW}$ ("Boulesoual") and the $\mathrm{pH}$ varied from 4.90 to 6.03 . 
Table 1 : Physicochemical characteristics of the dishes

\begin{tabular}{|c|c|c|c|c|c|c|}
\hline Dishes & Ash(DW) & $\% \mathrm{DW}$ & $\mathrm{pH}$ & (TSS) (g/l) & $\begin{array}{c}\text { TTA } \\
(\mathrm{meq} / 100 \mathrm{~g} \mathrm{FW})\end{array}$ & $\begin{array}{l}\text { Water content } \\
\text { (g/100g FW) }\end{array}$ \\
\hline “Koukoul”' & $5.93 \pm 1.61^{\mathrm{cd}}$ & $40.60 \pm 0.80^{d}$ & $4.93 \pm 0.21^{d}$ & $35.20 \pm 17.66^{a b}$ & $4312.50 \pm 718.07^{a b}$ & $59.40 \pm 0.80^{d}$ \\
\hline "'Boulesoual" & $4.75 \pm 0.27^{d}$ & $15.85 \pm 0.99 g$ & $5.06 \pm 0.18^{c d}$ & $54.70 \pm 15.51^{a}$ & $4875.00 \pm 37.00^{a}$ & $84.15 \pm 0.99^{a}$ \\
\hline “Malaxé of plantain” & $8.41 \pm 1.12^{b}$ & $33.45 \pm 3.73^{e}$ & $6.03 \pm 0.10^{a}$ & $26.20 \pm 3.46^{b}$ & $2062.50 \pm 37.00^{d}$ & $66.55 \pm 3.73^{c}$ \\
\hline “"Ntuba” & $7.38 \pm 0.52^{\mathrm{bc}}$ & $37.24 \pm 2.66^{\mathrm{de}}$ & $5.01 \pm 0.15^{d}$ & $27.70 \pm 3.00^{b}$ & $3562.50 \pm 37.00^{\mathrm{bc}}$ & $62.76 \pm 2.66^{\mathrm{cd}}$ \\
\hline "Boiled Plantain" & $5.78 \pm 0.22^{\mathrm{cd}}$ & $35.37 \pm 1.12^{\mathrm{de}}$ & $4.99 \pm 0.13^{d}$ & $32.20 \pm 6.00^{b}$ & $4125.00 \pm 433.01^{\mathrm{ab}}$ & $64.63 \pm 1.12^{\mathrm{cd}}$ \\
\hline “Fried Plantain” & $15.42 \pm 1.39^{a}$ & $53.17 \pm 5.16^{b}$ & $4.90 \pm 0.14^{d}$ & $35.20 \pm 8.48^{a b}$ & $4687.50 \pm 943.72^{a}$ & $46.83 \pm 5.16^{f}$ \\
\hline "Tisane de Plantain" & $6.11 \pm 0.80^{\mathrm{cd}}$ & $24.46 \pm 2.17^{f}$ & $5.59 \pm 0.18^{b}$ & $23.20 \pm 6.00^{\mathrm{b}}$ & $2250.00 \pm 0.00^{d}$ & $75.54 \pm 2.17^{b}$ \\
\hline “Roasted Plantain” & $5.81 \pm 1.35^{\mathrm{cd}}$ & $47.04 \pm 4.57^{c}$ & $4.91 \pm 0.03^{d}$ & $32.20 \pm 3.00^{b}$ & $4125.00 \pm 37.00^{a b}$ & $52.96 \pm 4.57^{e}$ \\
\hline
\end{tabular}

Mean values in the same column with different superscript letters are significantly different $(P<0.05)$.

\section{Mineral content of the recipes}

\section{Macro elements contents of the recipes}

The macro elements content of the 10 most consumed dishes made from either banana or plantain by the population of the East Region of Cameroo, $n$ are presented in table 3. Potassium levels were comprised between $257.94 \mathrm{mg} / 100 \mathrm{~g}$ DW ("Fried plantain") and 142.86 mg/100g DW ("Banana fritter"). Phosphorus contents ranged from $142.70 \mathrm{mg} / 100 \mathrm{~g} \mathrm{DW}$ ("Banana fritter") to $96.43 \mathrm{mg} / 100 \mathrm{~g}$ DW ("Boulesoual"), meanwhile Calcium contents ranged from 22.93 $\mathrm{mg} / 100 \mathrm{~g}$ DW ("Ntuba") to $10.42 \mathrm{mg} / 100 \mathrm{~g} \mathrm{DW}$ ("Boiled plantain").

Magnesium levels were comprised between $13.49 \mathrm{mg} / 100 \mathrm{~g}$ DW ("Boulesoual") and $8.82 \mathrm{mg} / 100 \mathrm{~g}$ DW ("Malaxé of plantain"). Sodium contents of the dishes varied from $4.05 \mathrm{mg} / 100 \mathrm{~g}$ DW ("Boulesoual") to $0.89 \mathrm{mg} / 100 \mathrm{~g}$ DW ("Fried plantain")

Table 2 : Macro elements contents of the dishes expressed in g/100 DW

\begin{tabular}{|c|c|c|c|c|c|}
\hline Minerals & $\mathrm{Ca}$ & $\mathrm{K}$ & $\mathrm{Mg}$ & $\mathbf{P}$ & $\mathrm{Na}$ \\
\hline "Ndengué" & $20.56 \pm 4.18^{a}$ & $230.66 \pm 55.1^{\mathrm{ab}}$ & $9.28 \pm 1.05^{b}$ & $127.74 \pm 22.46^{a}$ & $2.90 \pm 0.79^{a b c}$ \\
\hline "Koukoul" & $22.31 \pm 3.45^{a}$ & $240.09 \pm 90.63^{a b}$ & $10.14 \pm 0.23^{b}$ & $121.92 \pm 9.12^{\mathrm{a}}$ & $2.63 \pm 0.72^{\mathrm{abc}}$ \\
\hline "Boulesoual" & $21.50 \pm 1.51^{\mathrm{a}}$ & $223.75 \pm 13.28^{\mathrm{ab}}$ & $13.49 \pm 0.35^{a}$ & $96.43 \pm 0.00^{a}$ & $4.05 \pm 0.85^{a}$ \\
\hline "Malaxé of plantain" & $17.03 \pm 3.69^{a}$ & $205.31 \pm 33.57^{\mathrm{ab}}$ & $8.82 \pm 0.97^{b}$ & $122.19 \pm 54.61^{\mathrm{a}}$ & $2.36 \pm 0.65^{\mathrm{abc}}$ \\
\hline "Ntuba" & $22.93 \pm 1.52^{\mathrm{a}}$ & $235.85 \pm 21.46^{\mathrm{ab}}$ & $9.07 \pm 0.29^{b}$ & $105.48 \pm 21.87^{a}$ & $1.57 \pm 0.95^{c}$ \\
\hline "Boiled Plantain" & $10.42 \pm 2.08^{b}$ & $223.65 \pm 49.86^{\mathrm{ab}}$ & $9.87 \pm 0.56^{b}$ & $104.89 \pm 12.72^{\mathrm{a}}$ & $2.43 \pm 1.00^{\mathrm{abc}}$ \\
\hline "Fried Plantain" & $17.65 \pm 4.68^{a}$ & $257.94 \pm 13.92^{\mathrm{a}}$ & $9.44 \pm 1.05^{b}$ & $102.57 \pm 7.47^{a}$ & $0.89 \pm 1.05^{c}$ \\
\hline "Banana Fritter" & $17.82 \pm 5.65^{a}$ & $142.86 \pm 57.59 b$ & $9.63 \pm 0.82^{b}$ & $142.70 \pm 26.55^{a}$ & $3.77 \pm 2.00^{\mathrm{ab}}$ \\
\hline "Tisane De Plantain" & $19.67 \pm 1.70^{\mathrm{a}}$ & $246.67 \pm 2.88^{a}$ & $9.16 \pm 0.43^{b}$ & $98.25 \pm 29.77^{a}$ & $2.02 \pm 0.14^{\mathrm{abc}}$ \\
\hline "Roasted Plantain" & $10.66 \pm 0.58^{b}$ & $242.63 \pm 12.36^{a}$ & $9.77 \pm 0.01^{b}$ & $142.27 \pm 29.27^{a}$ & $1.89 \pm 1.69^{b c}$ \\
\hline
\end{tabular}

Mean values in the same column with different superscript letters are significantly different $(P<0.05)$. 


\section{Microelements contents of the recipes}

Table 4 highlights the micro elements contents of the 10 most consumed dishes made from banana or plantain by the population of the East region of Cameroon. Iron contents ranged from $10.86 \mathrm{mg} / 100 \mathrm{~g}$ DW ("Tisane de plantain") to $4.51 \mathrm{mg} / 100 \mathrm{~g}$ DW ("Roasted plantain"), while Zinc contents varied from $2.50 \mathrm{mg} / 100 \mathrm{~g}$ DW ("Koukoul") to $1.05 \mathrm{mg} / 100 \mathrm{~g} \mathrm{DW}$
("Roasted plantain"). Copper levels were low and comprised between $0.19 \mathrm{mg} / 100 \mathrm{~g}$ DW ("Tisane de plantain", "fried plantain") and $0.10 \mathrm{mg} / 100 \mathrm{~g}$ DW ("Ndengué", "Boulesoual"). Manganese contents varied from $0.06 \mathrm{mg} / 100 \mathrm{~g} \mathrm{DW}$ ("Roasted Plantain") to $0.03 \mathrm{mg} / 100 \mathrm{~g}$ DW ("Boulesoual", "banana fritter"). lodine contents ranged from $0.49 \mathrm{mg} / 100 \mathrm{~g}$ DW ("Boiled plantain") to $0.18 \mathrm{mg} / 100 \mathrm{~g} \mathrm{DW}$ ("Fried plantain").

Table 3 : Micro elements contents of the dishes expressed in $\mathrm{mg} / 100 \mathrm{~g}$ DW

\begin{tabular}{|c|c|c|c|c|c|}
\hline Mineral & $\mathrm{Fe}$ & $\mathrm{Zn}$ & $\mathrm{Cu}$ & Mn & $\mathrm{I}$ \\
\hline "Ndengué" & $6.32 \pm 0.31^{\text {cd }}$ & $2.31 \pm 0.77^{\mathrm{ab}}$ & $0.10 \pm 0.02^{c}$ & $0.04 \pm 0.01^{\mathrm{a}}$ & $0.43 \pm 0.27^{a}$ \\
\hline "Koukoul" & $9.26 \pm 0.99^{a b}$ & $2.50 \pm 0.66^{\mathrm{a}}$ & $0.12 \pm 0.01^{\mathrm{abc}}$ & $0.04 \pm 0.01^{a}$ & $0.42 \pm 0.21^{a}$ \\
\hline "Boulesoual" & $8.34 \pm 0.37^{b c}$ & $1.75 \pm 0.31^{\mathrm{ab}}$ & $0.10 \pm 0.01^{c}$ & $0.03 \pm 0.01^{a}$ & $0.33 \pm 0.07^{a}$ \\
\hline "Malaxé of plantain" & $6.97 \pm 1.48^{\mathrm{c}}$ & $1.84 \pm 0.77^{a b}$ & $0.16 \pm 0.04^{\mathrm{abc}}$ & $0.05 \pm 0.01^{\mathrm{a}}$ & $0.47 \pm 0.13^{a}$ \\
\hline "Ntuba" & $6.36 \pm 2.09^{c d}$ & $1.64 \pm 0.74^{\mathrm{ab}}$ & $0.13 \pm 0.06^{\mathrm{abc}}$ & $0.04 \pm 0.01^{\mathrm{a}}$ & $0.31 \pm 0.19^{a}$ \\
\hline "Boiled Plantain" & $6.74 \pm 0.61^{\mathrm{c}}$ & $2.30 \pm 0.37^{a b}$ & $0.12 \pm 0.04^{\mathrm{bc}}$ & $0.05 \pm 0.01^{\mathrm{a}}$ & $0.49 \pm 0.21^{a}$ \\
\hline "Fried Plantain" & $8.35 \pm 0.94^{b c}$ & $2.46 \pm 0.70^{\mathrm{ab}}$ & $0.19 \pm 0.02^{\mathrm{a}}$ & $0.04 \pm 0.01^{\mathrm{a}}$ & $0.18 \pm 0.20^{a}$ \\
\hline "Banana Fritter" & $6.45 \pm 0.50^{\mathrm{cd}}$ & $2.09 \pm 0.69^{a b}$ & $0.12 \pm 0.01^{\mathrm{abc}}$ & $0.03 \pm 0.02^{\mathrm{a}}$ & $0.34 \pm 0.06^{a}$ \\
\hline "Tisane De Plantain" & $10.86 \pm 1.02^{\mathrm{a}}$ & $2.21 \pm 0.50^{\mathrm{ab}}$ & $0.19 \pm 0.04^{\mathrm{ab}}$ & $0.05 \pm 0.02^{a}$ & $0.40 \pm 0.02^{a}$ \\
\hline "Roasted Plantain" & $4.51 \pm 0.48^{d}$ & $1.05 \pm 0.27^{b}$ & $0.18 \pm 0.01^{\mathrm{ab}}$ & $0.06 \pm 0.01^{\mathrm{a}}$ & $0.38 \pm 0.33^{a}$ \\
\hline
\end{tabular}

\section{Macronutrients contents and energy values of the recipes}

The macronutrients and energy contents of the 10 most consumed dishes made from banana or plantain by the population of the East region of Cameroon are presented in Table 5. The lipids content of the dishes varied from 12 to $32 \mathrm{~g} / 100 \mathrm{~g}$ DW respectively for "Roasted plantain" and "Malaxé of plantain". These two recipes also have the minimal and maximal values for protein and carbohydrate contents respectively $(0.50$ $12.21 \mathrm{~g} / 100 \mathrm{~g} D W$ and $47-81 \mathrm{~g} / 100 \mathrm{~g} D W)$. The energy values of the dishes were less than $530 \mathrm{Kcal} / 100 \mathrm{~g}$ DW. 
Table 4 : Macronutrients and energy contents of the recipes

\begin{tabular}{|c|c|c|c|c|}
\hline Dishes & $\begin{array}{c}\text { Lipids } \\
\text { (g/100gDW) }\end{array}$ & $\begin{array}{l}\text { Carbohydrates } \\
\text { (g/100gDW) }\end{array}$ & $\begin{array}{l}\text { Proteins } \\
\text { (g/100gDW) }\end{array}$ & $\begin{array}{l}\text { Energy value } \\
\text { (Kcal/100gDW) }\end{array}$ \\
\hline "Ndengué" & $13.35 \pm 1.02^{c}$ & $78.74 \pm 1.11^{\mathrm{ab}}$ & $1.91 \pm 0.58^{\mathrm{def}}$ & $442.70 \pm 5.43^{c}$ \\
\hline "Koukoul" & $30.65 \pm 3.67^{a}$ & $60.30 \pm 3.00^{d}$ & $3.13 \pm 0.49^{\mathrm{bcd}}$ & $529.52 \pm 21.61^{a}$ \\
\hline "Boulesoual" & $14.16 \pm 1.38^{c}$ & $78.42 \pm 1.55^{a b}$ & $2.67 \pm 0.77^{\text {cde }}$ & $451.80 \pm 7.51^{c}$ \\
\hline "Malaxé of plantain" & $32.25 \pm 4.20^{a}$ & $47.14 \pm 5.78^{e}$ & $12.21 \pm 1.74^{a}$ & $527.63 \pm 18.59^{a}$ \\
\hline “Ntuba” & $13.16 \pm 0.49^{c}$ & $75.26 \pm 0.93^{b}$ & $4.20 \pm 0.42^{b}$ & $436.28 \pm 3.92^{c}$ \\
\hline "Boiled Plantain" & $13.00 \pm 0.47^{c}$ & $77.68 \pm 0.61^{a b}$ & $3.55 \pm 0.50^{\mathrm{bc}}$ & $441.86 \pm 3.18^{c}$ \\
\hline "Fried Plantain" & $20.11 \pm 1.63^{b}$ & $63.20 \pm 1.69^{\mathrm{cd}}$ & $1.27 \pm 0.39^{\mathrm{ef}}$ & $438.90 \pm 11.29^{c}$ \\
\hline "Banana Fritter" & $23.96 \pm 1.54^{b}$ & $66.64 \pm 1.36^{c}$ & $4.55 \pm 0.18^{b}$ & $500.38 \pm 8.04^{b}$ \\
\hline "Tisane De Plantain" & $14.88 \pm 0.29^{c}$ & $77.49 \pm 0.84^{\mathrm{ab}}$ & $1.52 \pm 0.22^{\mathrm{ef}}$ & $449.99 \pm 4.27^{c}$ \\
\hline "Roasted Plantain" & $12.50 \pm 0.52^{c}$ & $81.18 \pm 2.46^{a}$ & $0.50 \pm 0.03^{f}$ & $439.26 \pm 5.02^{c}$ \\
\hline
\end{tabular}

Mean values in the same column with different superscript letters are significantly different $(P<0.05)$.

\section{DISCUSSION}

\section{Water and ash content}

The water content of the various dishes varied from one recipe to the other. "Boulesoual" and "Banana fritter" presented the maximum and minimum contents respectively. In fact the quantity of water used when preparing a recipe influences its water content. We then understand why "Boulesoual" which was prepared with about $1 \mathrm{~L}$ of water for $700 \mathrm{~g}$ of plantain pulp presented the highest water content. The result obtained in this case $(66.54 \%)$ is less than the $83 \%$ obtained by Kana Sop et al. (2008).

The water and ash content presented a negative correlation $(r=-0.383, p<0.021)$, this justifies the smallest ash content (4\% DW) obtained by "Boulesoual'. On the other hand, "Fried plantain" presented the highest content $(15.42 \% \mathrm{DW})$. In fact boiling usually leads to a significant loss of minerals due to their diffusion from food to boiling water (Cuq, 1992). Moreover the highest ash content of "Fried plantain" can result to the fact that frying favors minerals retention due to the migration of water particles from food to oil (Kawashima and ValenteSoares, 2003).

\section{Total titratable acidity (TTA) and $\mathrm{pH}$}

TTA and $\mathrm{pH}$ are negatively correlated $(r=-0,829, \mathrm{p}$ $<0,001)$, thus an increase in $\mathrm{pH}$ implies a decrease in
TTA in either banana or plantain. This therefore explains why "Malaxé of plantain" presented a low TTA in contrast with "Boulesoual" presenting a high TTA. The plantains used for the preparation of "Malaxé of plantain" were in stage 1 of ripeness while those used in the preparation of "Boulesoual" were in stage 6 to 8 of ripeness. It has been shown that acid levels present in bananas and plantains increase during ripening (Dadzie and Orchard, 1997). This is due to increase in acids content of the pulp particularly citric, malic and oxaloacetic acids Satyan et al. (1984).These results are in line with those of Kouamé et al. (2010) and Ngoh Newilah et al. (2011).

\section{Total soluble solids (TSS)}

The TSS gives information on banana and plantain maturity stage used in the recipes. A negative correlation was observed between the TSS and TTA rather than the $\mathrm{pH}$. Generally the TSS increases with fruit ripening ((Dadzie and Orchard, 1997), Ngoh Newilah et al.(2011). "Tisane de plantain" prepared with stage 1 plantain has a lower TSS while "Boulesoual" prepared with stage 6 to 8 plantain has a high TSS. This increase is the after-effect of metabolic processes occurring in banana fruits such as starch hydrolysis and accumulation of simples sugars such as glucose and fructose (Palmers, 1971) responsible for the sweetening of ripe fruit. These results are similar to those observed by Ngoh Newilah et al. (2011) during 
the ripening of some plantain cultivars and Musa hybrids grown in Cameroon

\section{Macronutrients and energy contents}

High proteins and lipids contents were observed in "Malaxé of plantain" while "roasted plantain" presented the lowest values. "Roasted plantain" is prepared without additional ingredient, while "Malaxé of plantain" is prepared with many ingredients (Table 1). The fish added in "Malaxé of plantain" helps to increase the protein level. The protein content of "Malaxé of plantain" $(12.21 \mathrm{~g} / 100 \mathrm{~g} \mathrm{DW})$ is comparable to the reference values $(15 \mathrm{~g} / 100 \mathrm{~g}$ DW) while the carbohydrates content of "Roasted plantain" is greater than reference values $67 \mathrm{~g} / 100 \mathrm{~g}$ DW Herberg et al.(1985).

"Koukoul" presented the highest energy content $(529.52 \mathrm{Kcal})$ while "Ntuba" presented the lowest energy content $(436.28 \mathrm{Kcal})$. The oil used in the "Koukoul" preparation can explain this difference because the energy bound by $1 \mathrm{~g}$ of lipids represents twice the energy bound by $1 \mathrm{~g}$ of carbohydrates (Atwater and Bryant, 1899). Despite its energy content "Koukoul" is poor in protein (3.13\%) and is usually eaten alone creating an imbalance in the daily food intake. In this context "Ntuba" which is consumed with sauces may be balanced if it is consumed with a protein-rich sauce. L'Agence Nationale de Sécurité Sanitaire de l'Alimentation et de l'Environnement du Travail (ANSES) recommends that the contribution of each macronutrient for a balanced food intake should be 45 to $50 \%$ for carbohydrates, $15 \%$ for proteins, 35 to $40 \%$ for lipids (ANSES, 2011). With its macronutrients contents $47.14 \%$ carbohydrates, $12.21 \%$ proteins and $32.25 \%$ lipids "Malaxé of plantain" can be classified as a balanced food, thus its consumption could help to improve the nutritional status of the population.

\section{Micronutrients}

\section{Macro elements content}

Potassium contents of all the analyzed dishes were low compared to those obtained by Kana Sop et al. (2008) in some household dishes consumed in Douala (Littoral region of Cameroon). Sodium contents of the dishes were low compared to those of some dishes consumed by some natives of Bassa plateau in Nigeria Madukorsiri et al. (2009). Sodium together with potassium ensures acid-base equilibrium in the human body. Unlike sodium, potassium decreases blood pressure in people suffering from high blood pressure while its deficiency increases the blood pressure Potier de Courcy et al. (2003), thus "fried plantain" consumption should be encouraged to people suffering from high blood pressure. Calcium contents of the analyzed dishes were higher compared to those reported by Sangita Sharma et al. (2007) in "Pounded plantain" $(5.4 \mathrm{mg} / 100 \mathrm{~g} \mathrm{DW})$. Calcium contributes to bones and teeth formation and maintains them in good health (Wardlaw and Smith, 2007). "Ntuba" consumption should be encouraged for children and people suffering from osteoporosis. Phosphorus and magnesium contents of the dishes were low compared to those obtained by Kana Sop et al. (2008) in some households consumed in Douala (Littoral Region Cameroon). Magnesium is the constituent of bones and teeth, and is a cofactor of many enzymes Murray et al. (2000).

\section{Micro elements content}

The iron contents of the dishes were highest compared to those reported by Ponka et al. (2005). Iron deficiency is responsible for anemia (Passeport santé, 2015), thus the consumption of "Tisane de plantain" should be encouraged to people who are more exposed to iron deficiencies (children under 5 years and pregnant women). Zinc contents of the dishes were higher compared to those obtained by Honfo et al. (2008) in some foods made from banana or plantain consumed in Cameroon. Zinc is important in cell renewal, healing and immunity (Black, 2003). Copper contents were lower compared to those of some Cameroonian's households consumed in Douala (Littoral region of Cameroon) reported by Kana Sop et al., (2008). Copper is necessary in red blood cells formation and lymphocytes replication, thus it stimulates the immune system (Burke and Miller, 2006). Manganese contents of the analyzed dishes were low compared to those reported by Morakinyo et al. (2016) on some commonly consumed local foods in Nigeria. Manganese is the constituent of the enzyme super oxide dismutase (SOD), and thus prevents the damage caused by free radicals (Institute of Medicine, 2001).

\section{CONCLUSION}

The aim of this study was to describe and determine the nutritional and physicochemical characteristics of dishes made from banana or plantain consumed in the East Region of Cameroon. The following conclusions were drawn from the study: - Bananas and plantains represent the most abundant ingredient present in all the recipes - The maximal contents of $\mathrm{K}, \mathrm{P}, \mathrm{Ca}, \mathrm{Mg}$, $\mathrm{Na}, \mathrm{Fe}, \mathrm{Zn}, \mathrm{Cu} \mathrm{Mn}$ and I were found in "fried plantain", "banana fritter", "Ntuba", "Boulesoual', "Boulesoual" "Tisane de plantain", "Koukoul", "Tisane de plantain", "Roasted plantain" and "boiled plantain" respectively The lipids content of the dishes varied from 12.5 to $32.25 \mathrm{~g} / 100 \mathrm{~g}$ DW respectively for "Roasted plantain" and "Malaxé of plantain". These two recipes also have the minimal and maximal values for protein and carbohydrates contents respectively $(0.50$ $12.21 \mathrm{~g} / 100 \mathrm{~g} \mathrm{DW}$ and $47-81 \mathrm{~g} / 100 \mathrm{~g} \mathrm{DW}$ ) - The energy values of the dishes were less than $530 \mathrm{Kcal} / 100 \mathrm{~g}$ DW. Recipes generally containing plantain and other ingredients are usually balanced as it is the case of "Malaxé of plantain" (47.14\% carbohydrates, $12.21 \%$ proteins and $32.25 \%$ lipids) which can cover the recommended daily food intake. The data obtained in the framework of this study will contribute to the establishment of composition table of foods derived from bananas and plantains in Cameroon. 


\section{ACKNOWLEDGEMENTS}

We are very grateful to CARBAP (African Research Centre on Banana and Plantain) for supporting this study under the framework of FSTP2-European Union project. We also thank the population of the East region of Cameroon for their participation during the nutritional survey.

\section{REFERENCES}

AGRI-STAT (2012). Annuaire des Statistiques du Secteur Agricole Campagnes 2009 et $2010 \quad\left(n^{\circ}\right.$ 17). Cameroun : MINADER / DESA / AGRI-STAT.

ANSES (2011). Actualisation des apports nutritionnels conseillés pour les acides gras. Rapport d'expertise collective. p. 327.

Atwater WO and Bryant, AP (1990). The availability and fuel value of food materials. Conn. (Storrs) Agricultural Experiment Stations 12th Annual Report 1899, p. 73-110. Storrs, CT, USA.

AOAC (1980). Official methods of analysis of the Association of Official Analytical Chemists. $13^{\mathrm{e}} \mathrm{ed}$. Washington, DC, Etats-Unis: Association des chimistes analytiques officiels.

Black RE (2003). Zinc deficiency, infectious disease and mortality in the developing world. Journal of Nutrition, 133:1485-1489.

Bourely J (1982). Observation sur le dosage de l'huile des graines de cotonnier. Coton et Fibres Tropicales. 27 (2): $183-196$.

Burke JM and Miller JE (2006). Control of Haemonchus contortus in goats with a sustainedrelease multi-trace element/vitamin ruminal bolus containing copper. Journal of Veterinary Parasitology, 141: 132-137.

Chandler S (1995). The nutritional value of bananas. In S. Gowen, (dir.), Bananas and Plantains p.468480. UK: Chapman and Hall.

Cuq JL (1992). Qualité de nos aliments et technologie. In Dupin, H. (dir.), Alimentation et nutrition humaine. $p$ 1235-1257. Paris : ESF.

Dadzie BK and Orchard JE(1997). Routine Post Harvest Screening of Banana/Plantain Hybrids: Criteria and Methods. INIBAP Technical Guidelines (no 2). International Plant Genetic Resources Institute, Rome, Italy; International Network for the Improvement of Banana and Plantain, Montpellier, France; ACP-EU Technical Centre for Agricultural and Rural Cooperation, Wageningen, The Netherlands.

Dupin H, Lauret B, Lucette B and Baudier F (1996). Aliments, alimentation et sante, questions réponses. Paris: Tech. \& Doc. Lavoisier. Groupe de recherche en éducation nutritionnelle (GREEN).

Dury S, Bricas N, Tchango J, Temple L, and Bikoï A (2002). The determinant of urban plantain consumption in Cameroon. Food Quality and Preferences, 32: 81- 88.

Herberg S, Dupin H, Papez L, and Galan P (1985). Recherches sur les relations entre alimentation et risque de survenue de certains cancers. Apport des études épidémiologiques. In : nutrition et santé publique, approche épidémiologique et politique de prévention. Techniques de documentation. Lavoisier, Paris, 557-582.

Honfo FG, Kayodé APP, Coulibaly O, and Tenkouanou A (2007). Relative contribution of banana and plantain products to the nutritional requirements for iron, zinc and vitamin $A$ of infants and mothers in Cameroon. Journal of Fruits, 62 (5): $267-277$.

Inge D, Brouwer, Alfred S, Traoré and Trèche S(2004). Food based approaches for a healthy nutrition in West Africa: The role of food technologists and nutritionists. In Inge D. Brouwer, Alfred S. Traoré, Serge Trèche (Eds). Proceedings of the 2nd international workshop, p. 277. Ouagadougou, 2328 Nov 2003.

Institut National de la Statistique (INS) (2012). Enquête Démographique et de Santé à Indicateurs Multiples du Cameroun 2011. Calverton, Maryland, USA : INS et ICF International.

Institute of Medicine (IOM)(2001). Food and Nutrition Board. Dietary Reference Intakes for Vitamin A, Vitamin K, Arsenic, Boron, Chromium, Copper, lodine, Iron, Manganese, Molybdenum, Nickel, Silicon, Vanadium, and Zinc. Washington, DC: National Academy Press.

Josylin MA (1970). Acidimetry In Methods in food analysis (M. A. Josylin, ed.). Academic Press, New York, 401-559.

Kana Sop MM, Gouado I, Teugwa C, Miri S, Fotso,M and Tetanye Ekoué (2008). Mineral content in some Cameroonians household foods eaten in Douala. African Journal of Biotechnology, 7 (17): 3085-3091.

Kawashima LM and Valente-Soares LM (2003). Mineral profile of raw and cooked leafy vegetables consumed in Southern Brazil. Journal of Food Composition and Analysis 16: 605-611.

Kumar S, and Aalbersberg B (2006). Nutrient retention in foods after earth-oven cooking compared to other forms of domestic cooking. Journal of Food Composition and Analysis, 19: 311-320.

Kouamé R, N'ganzoua, Camara B and Dick E (2010) Evaluation des changements physico-chimiques caractérisant le mûrissement au cours de l'entreposage de trois variétés de bananes Musa spp. (AAB, cv. Corne 1 ; AAA, cv. Poyo et AA, cv. Figue Sucrée), sciences naturelles, 7 (2) :155 163.

Madukorsiri, Chinyelu H and Adoga GI (2009). Some Nutrient Composition of Ready-to-Eat Foods Consumed by Pregnant and Lactating Women in Bassa LGA of Plateau State, Nigeria. Pakistan Journal of Nutrition 8: 1889-1893.

Morakinyo AO, Samuel TA and Adegoke OA (2016). Mineral Composition of Commonly Consumed Local Foods in Nigeria. Afr. J. Biomed. Res. 19: 141- 147.

Murray RK, Granner DK, Mayes PA and Rodwell VW (2000). Harper's Biochemistry, 25ed. USA: McGraw-Hill, Health Profession Division.

Ngoh Newilah G, Tchango Tchango J, Fokou E, Dury $S$ and Etoa FX (2005). Processing and food uses 
of bananas and plantains in Cameroon. Fruits 60 (4): $245-253$.

Ngoh Newilah G, Kodjo Tomekpe, Fokou E, and Etoa FX (2011). Effect of ripening on physicochemical composition of plantain cultivars and Musa hybrids grown in Cameroon. Fresh Produce - Global Science Books 5 (1): $61-68$.

Palmer JK (1971). The banana. In, Hulme, A. C. (dir.). The Biochemistry of fruits and their products p.265-105. London: Academic Press.

Passeport Sante.Net (2015). Les minéraux leurs fonctions et les sources. Retrieved on September 22 nd $, \quad 2015, \quad$ from website :www.passeportsante.net/fr/Solutions/PlantesSupp lements/Fiche.aspx?doc=cafe ps.

Pauwels JM, Van RanstE, Verloo $\mathrm{M}$ and Mvondo Ze A (1992). Manuel de laboratoire de pédologie Méthode d'Analyses de Sols et de Plantes, Equipement, Gestion de Stocks de Verrerie et de Produits Chimiques. Publications Agricoles (no 28) édité par l'AGCD.

Ponka R, Fokou E, Fotso M, Achu MB, and Tchouanguep FM (2005). Methods of preparation and the energy, protein and mineral values of three Cameroonian dishes: Corn Chaf, Nnam Owondo/Ebobolo and Nnam Ngon Ebobolo. African Journal of Food Agriculture and Nutritional Development (AJFAND). 5(1): 1-12.
Potier de Courcy G, Frelut ML, Fricker J, Martin A et Dupin H (2003). Besoins nutritionnels et apports conseillés pour la satisfaction de ces besoins. EMC (Elsevier Masson SAS, Paris), Endocrinologie-Nutrition, 10-308-A-10, 2012.

The World Bank (2006). Repositioning nutrition as central to development: a strategy for large scale action. Directions in Development. Washington, DC. $21 p$

Tchango Tchango J.and Ngalani JA(1998). Transformation et utilisation de la banane plantain en Afrique centrale et occidentale. In, INIBAP (dir.), Banana and food security : Les productions bananières un enjeu économique majeur pour la sécurité alimentaire p.361-373. Montpellier: INIBAP.

Trèche (1989). Risques liés aux variations de la valeur nutritionnelle des aliments : le cas des tubercules cultivés au Cameroun. In : Risque en agriculture, ORSTOM, Paris, 375-394.

Tremolieres J, ServilleY and Jacquot R(1984). Manuel d'alimentation humaine: les aliments $10^{\circ} \mathrm{ed}$, Paris : ESF.

Wardlaw GM and Smith AN (2007). Contemporay Nutrition. ( $\left.7^{e} e d.\right)$ : McGraw Int. 